\title{
Innovative Methods in Teaching English to Adults
}

\author{
Svetlana E. Kaplina* \\ Transbaikal State University \\ 30 Aleksandro-Zavodskaya Str., Chita, 672039, Russia
}

Received 24.07.2015, received in revised form 18.09.2015, accepted 23.10.2015

\begin{abstract}
The article is devoted to description of innovative methods to adults. Innovative methods and technologies of teaching today are gaining increasing recognition and new opportunities associated with the establishment of interpersonal interaction. The author pays attention to choices of methods which should vary with different purposes, ages groups, and stages of mental development. A structure of modern process of teaching and its results is presented by the author. Some of the common learning characteristics of adult language and literacy learners as well as four guiding principles to teaching adults foreign languages are given in the article. In accordance with the selected characteristics and guiding principles the author considers it necessary to use some of innovative methods for teaching adults. Among them there are such methods as: method of direct instruction (J. Wiechmann and J. Grell), method of electronic self-directed education (T.M. Balykhina), method of pedagogic studio work (E.V. Nevmerzhitskaya), method of interdisciplinary projecting (S.E. Kaplina). The main methodological characteristics of the methods are described in the article as well.
\end{abstract}

Keywords: teaching adults, innovative methods, teaching process, direct instruction, electronic selfdirected education, pedagogic studio work, interdisciplinary projecting.

The article is written with the financial support of the European Commission within the Tempus IV programme (Project "Lifelong Language Learning University Centre Network for New Career Opportunities and Personal Development (UNICO)”, № 544283-TEMPUS-1-2013-1-ES-TEMPUSJPHES).

DOI: $10.17516 / 1997-1370-2015-8-11-2437-2447$.

Research area: pedagogy.

\section{Introduction}

Modern methodology is rich in teaching methods and principles. Each of them has its own advantages and disadvantages, merits and defects, but none is perfect. So, it is very important to find out the exact method of teaching in a particular case. We share the view of Chen Jiamy, who considers that the best method is one where a specific effect is obtained in a specific context. Choices of methods, then, should vary with different purposes, ages groups, and stages of mental development, etc (Chen Jiamu, 1997).

Today the transformations, which are actively occurring in our country, have lead to people's demand for learning foreign languages.

(C) Siberian Federal University. All rights reserved

* Corresponding author E-mail address: kse2000@list.ru 
Most of them are looking forward to acquiring such a level in knowing language when he / she has certain basic skills of a foreign language and will possess all the qualities necessary for selfperfection of knowledge in it. Some of them need foreign languages to be able to communicate in everyday life, the other - to be effective in profession and adjoining spheres of activities. So, the results of their learning a foreign language are to be factually learned knowledge and competencies, personal development, selfdependence and creative search, an ability to continue learning the language on a higher level. To realize this task it is necessary to organize educational process in such a way so that it assists in effective realization of people's aims in learning foreign languages.

\section{Modern process of teaching foreign languages}

In our opinion a modern process of teaching and its results has the following structure (Fig. 1).

Knowledge. A whole complex of person' awareness is included in it:

- awareness about language structure: sounds, letters, parts of speech, etc;

- awareness about the level of language possession, and conditions of its further development in every particular sphere.

Abilities. The abilities are considered as a complex structural formation which includes sensitive, intellectual, willing, creative, emotional qualities of a personality, helping him / her in achieving his / her goal in learning foreign languages. The abilities are interrelated with experience acquirement in the sphere of person's activity.

Skills. The skills are suggested to develop person's readiness to perform fluent communication in English and creative acts while solving different tasks:

- on the level of reading, writing, listening, speaking;

- on the level of confident use of the received knowledge in practical activity or work.

The formation of knowledge, abilities and skills of students in learning foreign languages are to be considered the main indicator of competencies development (general and specific ones).

\section{Teaching foreign languages to adults}

Speaking about teaching adults we must say that it can be a very rewarding and enriching experience. In terms of the teaching of English to adults, the right methods to adopt should be multipurpose-oriented, mainly concerned with the characteristics of adults. In others words, with a fully developed mental power, the adults' own modes of thinking, memory capacity, imitation ability, strengths and weaknesses, etc., and above all, how to make the best of them are the starting

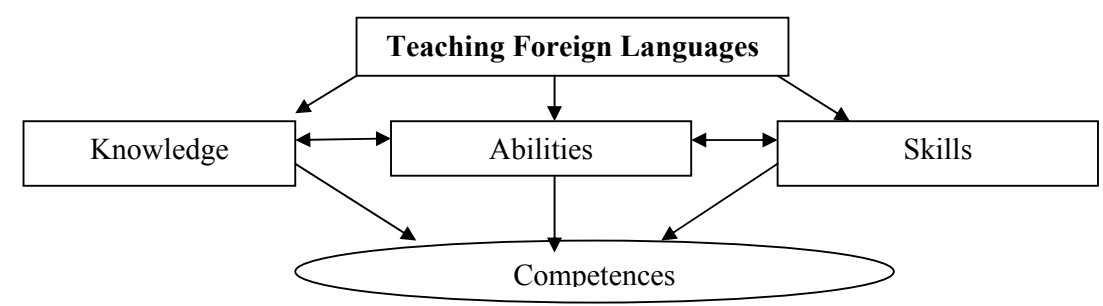

Fig. 1. The structure of teaching foreign languages 
points for decisions about teaching methodology (Chen Jiamu,1997).

Today we consider it necessary to use innovative methods and technologies in teaching English to adults. Innovative methods and technologies represent an innovative trend in education, based on domestic and global trends, best practices and traditions (Averkin V.N., Bogolyubov V.I., Bordovsky G.A., Voltchkov A.P., Gershunsky B.O., Zagvyazinsky V.V., Kan Kalik V.A., Krayewsky V.V. et al.).

In accordance with the definitions of most dictionaries «innovation» is an introduced innovation, providing qualitative growth of processes or products' efficiency required by the market. Innovation is the final result of human intellectual activity, his imagination, creative processes, discoveries, inventions and rationalization.

Today, the concept of «innovation» is interpreted broadly. In the world economic literature repeatedly emphasizes the connection between the ideas of potential scientific and technological advances and their reality in new products and technologies (Makoveeva, 2012). Innovation is defined as the process in which an invention or idea acquires the economic content (Kustov, 1990). Joseph Schumpeter treats innovation as a new scientific and organized by a combination of production factors, motivated entrepreneurial spirit (Makovveeva, 2012).

With regard to education innovation is considered to be the result of introduced innovation, which is revealed in the form of new content, methods, forms of organization of educational process or advanced technical training tools used in practice, or a new approach to social services in the field of education (Zainiev, 2012).

Innovative methods and technologies of teaching today are gaining increasing recognition and new opportunities associated with the establishment of interpersonal interaction through external dialogue in the process of assimilation of educational material, as well as contribute to the implementation of the principle of continuity of knowledge transfer, formation of competencies, personal qualities and meta-professional ones.

As for teaching adults it should be effective first of all. Part of being a successful adult educator involves understanding how adults learn best. Adults have special needs and requirements as learners. That's why the methodologists point out some of the common learning characteristics of adult language and literacy learners (Global Talent Bridge):

1) Adult learners are goal-driven.

2) Language and literacy are social processes that involve interaction with others.

3) Language and literacy development require risk taking.

4) Language and literacy develop when the target language is slightly above the current level of proficiency of the user.

5) Language and literacy development require focus, engagement and practice.

6) Language and literacy are multidimensional and require different kinds of interactions with different kinds of genres.

7) Language and literacy develop through interactions with tasks that require cognitive involvement.

8) Language and literacy develop more deeply if skills are connected to an overall topic, theme or context.

There are four guiding principles to teaching adults foreign languages. They are:

1) Instruction should be made as meaningful as possible to the adult learner by making use of the learner's prior content, workplace or professional knowledge.

2) Direct use in the classroom is made of materials, tools, equipment and «things» («realia») that the learner will actually use after training. 
3) English language skills are improved at the same time that the learner's content knowledge, information knowledge, processing skills, discourse skills, turn-taking skills, cross-cultural skills and sociolinguistic skills are improved.

4) Valid assessment of learning requires context/content specific measurement.

\section{Innovative methods and technologies of teaching}

Innovative methods and technologies of teaching today are gaining increasing recognition and new opportunities associated with the establishment of interpersonal interaction through external dialogue in the process of assimilation of educational material, as well as contribute to the implementation of the principle of continuity of knowledgetransfer, the formation of competencies, personal and meta-professional qualities of students. As for us we consider it necessary to use some of innovative methods for teaching adults as they respond to the above mentioned principles and characteristics of adult language teaching. Among them there are such methods as: method of direct instruction (J. Wiechmann and J. Grell), method of electronic self-directed education (T.M. Balykhina), method of pedagogic studio work (E.V. Nevmerzhitskaya), method of interdisciplinary projecting (S.E. Kaplina).

Method of direct instruction. This method was proposed by German researchers and educators Jochen Grella and Jürgen Wichmann. The essence of the method is to achieve a more informed perception of educational material to learn, active orientation of the target. This approach contributes to the efficient perception of the material by learners. The teacher in the classroom is given a central role in managing the overall development of events.

The starting point of the method is the evaluation of the direct instruction teaching success, regardless of the study discipline and the individuality of a teacher. A. Hemlke has once said: «No other sign is not so unequivocally and consistently associated with the level of labour productivity and educational progress of groups of learners as instruction of class or group» (Mendygalieva, 2009).

In implementing the method of direct instruction the teachers should:

- focus on the concentration of clear, a specialized formulation of the problem;

- pay attention to result providence of the lesson, simultaneously preventing learners' possible withdrawals from lesson's theme;

- support the mobile nature of the learning process, using in the course of instruction short remarks of individual character (in the form of questions, case assignments, etc.) that enhance the effectiveness of the educational process;

- give a small explanation when learners have difficulties while perception of the material;

- contribute to the belief in the success of learners, actively supporting the initiative shown by them;

- being an authority in the field of teaching, do not behave authoritatively that allows to design a lesson in accordance with the rules of correct communication between object and subject of the educational process (Wiechmann, 2006).

The effectiveness of the method is demonstrated by various forms of training. The lesson during which the method of direct instruction was used can be considered successful if three major steps to achieve the goal are passed: general presentation and demonstration of the lesson's goals and objectives; performance of tasks under the supervision of teacher and individual exercises without teacher's instruction. The effectiveness of the method of direct instruction is 
achieved under the conditions of implementation in the educational process: orienting introduction at the beginning of the lesson, independent presentation of the assignment after the lesson and the resulting check at the next lesson.

It is important to note that this method makes it possible to use the training time advantageously, the less of which is given to informing of students, learning the material, discussion of the proposed tasks. The teacher controls the training, trying to involve all learners in the process of cooperation. The use of direct instruction is appropriate during the role-playing game, performing practical tasks, group dynamic seminars, laboratory work.

The founder of the electronic self- directed method is considered to be T.M. Balykhina. Depending on the purpose, motive, terms of e-learning method is based on a variety of tools and technologies that can be used as self-study; controlled learning; training, instructor-directed; embedded training and distance learning.

The purpose of introducing the electronic self- directed method of learning is to transfer the knowledge to highly independent learners (those who wish to receive education on their own terms).

Based on the traditional methods and forms of teaching this method is enriched with modern ICT that meets one of the leading requirements of education in Russia, its informatization. The use of ICT in one's own activity as a part of the competency of person's image promotes the individual's development, as well as disclosure of creative and intellectual abilities of the individual at all levels of education.

The method during preparing or carrying out practical tasks may include such forms of work as multimedia presentations, web-pages and other interactive tutorial information. Moreover, all instructions are given in the self-study course materials, as self-learning is often deprived of the opportunity to clarify difficult points from the instructor, ask for «help» because of the territorial remoteness.

Built-in (embedded) courses is another type of electronic self- directed method, providing training on demand: such courses are usually embedded in computer programs, help files, webpages or web applications, making the learning process continuous. Embedded e-learning programs can be located in the web-is, or on a learner's computer.

The means of e-learning tools often depend on the nature of dialogue organization, which usually occurs between the parties of the educational process and can be synchronous or asynchronous.

Synchronous interactions occur in real time, i.e. all participants are in the network at the same time. Media components of synchronous interaction include sharing chats, applications, white-boards, audio and video conferencing.

Asynchronous interactions do not require simultaneous presence of the participants in the network. Asynchronous media components include email and online discussion forums.

Collaboration tools such as an online discussion forum is a kind of message board, news way to exchange ideas; white board is a tool that allows you to share graphic images and collaboration tool that simulates the activity of the instructor when he paints academic information on the board, involving learners in the process; chats means enabling instant messaging, webTours and travel is a means and method of the academic «journey» after the leader over the Internet; unilateral (training slide shows what is perceived, accompanied by an explanation of learners) and bilateral presentation (the latter allows learners to ask questions during the presentation, make comments, otherwise participate in an event, etc.) - make it possible to free interaction of remote learners to solve general educational problems. 
While using the method pedagogic studio work in educational process, the main aim of a lesson consists in receiving by student additional topics unfixed in educational programmes with the help of a teacher under obligatory expressed initiative of student in mastering new knowledge (Wiechmann, 2006). The German researcher Valdemar Pallasch while describing the didactic meaning of the method pedagogic studio work, points out, that it «allows radically to reconstruct educational process by means of space design of a work situation», and underlines «the role of a teacher as a guide and assistant in solving working processes» (Fig. 2).

The method of pedagogic studio work was suggested by E.V. Nevmerzhitskaya and includes 8 methodical working steps, which structure, discipline and gradually brings students and teachers to its effective realization (Nevmerzhitskaya, 2012).

Preparatory affairs. The main condition of pedagogic studio successful work is identification of a theme which can become a real problem for a study group challenge for constructive decision.

Together with the main thematic task one should pay attention to two aspects: time interval which is necessary for solving a problem and decoration of productive room. The supervisor of the pedagogic studio must be able to plan such amount which will be enough for taking the right decision by the learners. The decoration of a productive room is also an important element of successful realization of the method. In most cases usual classroom can be reequipped for so called creative studio, laboratory and equipped by additional labour means. The teacher has to decide what move furniture in the room is needed and what materials can be required for. On the contrary, normal working process can be slowed and even stopped. After successful fulfillment of preparatory works one can proceed to 8 methodical working steps (Fig. 3).

The work of pedagogic studio is such a model the success of which in most cases depends on the activities in situations under the teacher's conduct. At the same time special attention should be paid to strict compliance with fulfillment of methodological steps during the learners' work according to a calendar plan.

The use of new methods in education is always accompanied by certain emotions. The four leading principles of pedagogic studio work will help to formulate and direct them to use of the innovative method.

- Participation principle. All participants of the process have an ability to influence its course and result at any time.

- Structure defining principle. The working process is devoted to a didactic task to take into consideration certain studypsychological criteria during the task's fulfillment.

- Integral principle. The working process includes all possible types of study lessons. It actively accustoms a particular member of the studio as well as all its participants, the whole group, to optimal

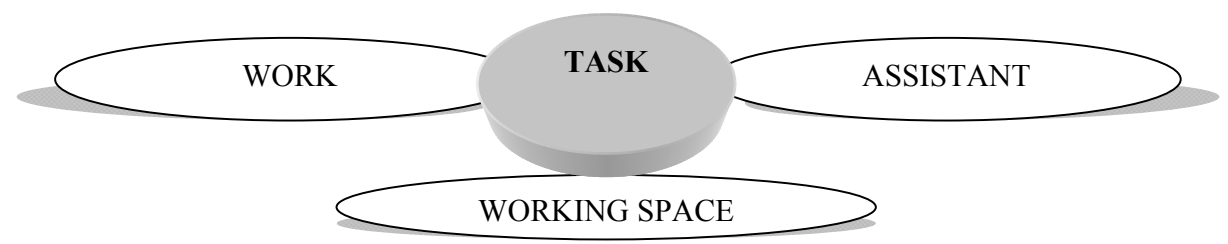

Fig. 2 The structure of the method pedagogic studio work 


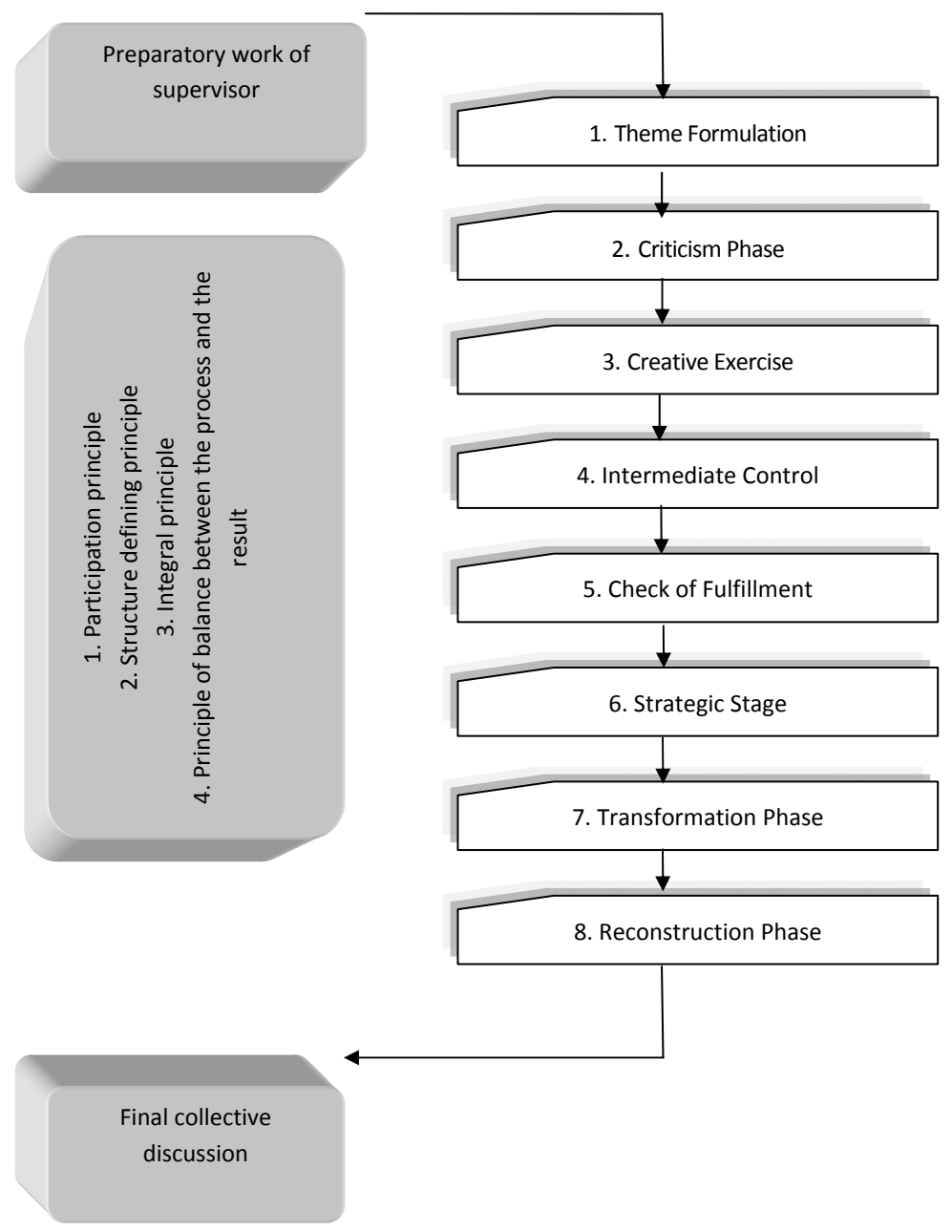

Fig. 3 Totality of didactic activities in the framework of pedagogic studio work

use of creative potential during fulfillment of tasks.

- Principle of balance between the process and the result. The result means not only observed or producible results of study labour at the end of the working process, but also the effectiveness in general depending on the achievements of every participant (the attained knowledge) and the whole group (community) of education process.

According to this method the central phase is the reconstruction one which supposes communication with the participants of the studio. That's why from the methodological point of view the study and work's discussion of the studio's supervisor requires collective consideration with the other teachers in a form of pedagogic conference, round table, etc. where different views of everyone on the question of method's realization can be presented. The method of pedagogic studio work is recommended to be used at the advanced levels of teaching adults, being an alternative to formal or informal education.

Another method used at the advanced levels of teaching adults is the method of interdisciplinary projecting proposed by S.E. Kaplina (2013). 
During training with the help of above mentioned method the learners acquire new knowledge, abilities, and skills and also master the complex of professional and special competences. Active creative work is a powerful stimulus for new ideas' appearance, foundation for the main types of thinking development and a push to performing of independent professional activity.

Such kinds of projects are made during free time and require distinct coordination of all participants of the project and a well-worked form of intermediate system of control and final presentation.

The use of innovative method of interdisciplinary ecological projecting will have a success under the following conditions:

- creation of necessary motivation which guaranties definite interest to the content of the problem under consideration;

- importance of information and its value for the learners, which was got during the consideration and solving of a particular problem;

- reflection of interdisciplinary ties of the formulated problem in methods, forms and means of projecting realization.

The background of innovative method of interdisciplinary is presented by specially worked out professionally integrative and intensively communicative technology of training.

The target aspect of technology is to stimulate an interest to professional problems through self-research activities, performing of creative tasks with the use of knowledge received while studying different subjects.

The planned result is the formation of professionally important personal and intellectually-logical abilities while performing different projects directed to the solving of global, socially-vital problems.

The technology is based on three components: knowledge, actions, subjectivity (variety of psychological abilities and mechanisms, which include intellect, senses, impulses, will and character of a man). The content of technology corresponds to the requirements of a contemporary professional. The characteristic features of the technology are variety of the training stages (theoretical, practical, moral-psychological) and conditions which influence the effectiveness of education, and also simultaneity, providing the use of methods, forms and means of several pedagogic technologies at a time, which help to form a personality.

The suggested professionally integrative and intensively communicative technology, which is the basis of projecting, gave us an opportunity to formulate a number of tasks to be solved by a teacher according to the stated goal, in particular:

- stimulation and motivation of consciousness and professionalism in the sphere of acquired profession development;

- actualization of professional and personal potential;

- formation of meta-professional components: general knowledge, abilities, skills, activities and competences;

- acquiring of experience in qualitative fulfillment of professional work;

- broadening of the content of educational programmes by means of using interdisciplinary ties between humanitarian and natural disciplines;

- providing subject to subject interaction between all the participants of professional-educational process.

Firstly, interdisciplinary projecting is oriented to the development of learners' independence, their intellectual, notional and creative activities; secondly, it allows organizing educational process according to professionally integrative and intensively communicative 
technology; thirdly, it stimulates consciousness development and competence formation of learners.

It goes without saying that the central component of projecting education is a project. The main characteristics of a project are novelty, originality and possible realization on practice. Besides, the displaying of independence by the learners, encouragement of their untraditional approaches to solving the existing professional problems corresponds to modern tendencies of professional education reform, when a learner becomes an active participant of educational process who is able to influence it but not remaining a receiver of the prepared educational product.

The interdisciplinary project has a lot of kinds and varieties. During the work the following projects can be used:

- oriented to practice project deals with social interests of the project's participants and can put into life of a region, town, state;

- investigative project is an independent scientific research with the use of modern scientific methods: laboratory experiment, modeling, social inquiry, interview, etc.

- informational project is often directed to information accumulation, its analyses, observation and presentation to mass public. Such project is usually «poured» into Internet publications, mass media;

- creative project is considered to be enough free in presentation and typography of the results. It can be presented in a form of a seminar, small plays, advertizing roller, films, etc.

- role-project is the most difficult one from the point of development and realization. The participants try on themselves certain roles, sometimes of imaginary heroes. The results of such projects can be unpredictable till the end of the whole project.

The participation in realization of project demands for learners' optimization of their social and creative activity. The aims of professional and personal development are realized on the level of social activity and only in joint activity and dialogic interaction. Similar projects expect usage of knowledge, abilities, skills which learners have received at the previous stages of education while learning all subjects.

Being without usual informative base on the already known facts, every participant of a project tries to find and select means and ways of solving the pointed in the project problems, build a number of adequate acts to contribute his possibilities into the creation of a qualitative project. It is the so-called creative process during which spontaneous storing of information takes place, the algorithm of scientific research is learned, the outlook different fields is strongly broadened.

It is important to take into consideration the fact that modern learners' interest in participating in projects can be achieved by means of substantial system of stimulation. That's why it is necessary to foresee the forms of moral and pecuniary stimulation of a project's participants. This may be conditional as well as real awards, grants, presents and other bonuses for the best project.

\section{Conclusion}

So, there are so many different innovative methods of teaching adults which together with the traditional ones help us to instruct adults while learning foreign languages and organize the work in class. To conclude, the major concern is aiming at how to achieve the best result or a relatively better one in a given context. Adoptions of teaching methods involve such factors as purposes, age groups and stages of mental development. In our opinion the method of direct instruction and the 
method of electronic self-directed education are comparatively found suitable for adult beginners while method of pedagogic studio work and the method of interdisciplinary projecting are advisable suggest for those at intermediate and advanced level. Guided composition should be practised, combining two or three, even four skills together.

\section{References}

Adult ESL Classroom Strategies and Lesson Ideas. Chapter 3. Global Talent Bridge. (2012), Available at: http://www.globaltalentbridge.org/toolkit/pdf/CH3_ESLStrategies.pdf (accessed 15 October, 2015).

Bolshaya Sovetskaya Entsiklopediya. [Large Soviet Encyclopedia]. Moscow, Soviet Encyclopedia. Vol. 20, 1957. 514 p.

Chen Jiamu (1997). The right methods for adults. On English acquisition/learning. Análise Psicológica, 4 (XV), 587-593.

Kaplina S.E. (2013). The project's work organization based on the interdisciplinary ecological projecting method. Secondary professional education, 4, 11-2.

Kustov Yu.A. Preemstvennost' obucheniya v professionalnoy I vysshey shkolah [Succession of teaching in professional and high schools]. Sverdlovsk, ed. UrGPU, 1990. $117 \mathrm{p}$.

Makoveeva V.V. (2012). Network interaction a key development factor of education, science and business integration. Tomsk State University Journal, 354, 163-166.

Mendygalieva A.K. (2009). Problems of succession of person's formation. ChGPU Journal, 3, $107-118$.

Nevmerzhitskaya E.V. (2012). Method of pedagogic studio work. Secondary Professional Education, 2, 18-20.

Nevmerzhitskaya E.V., Kaplina S.E. Innovatsionny vector professionalnogo razvitiya [Innovative vector of education development]. Moscow, Granitsa, 2012. 288 p.

Wiechmann, J. School pedagogics [Schulpädagogik]. 2. Aufl., Baltmannsweiler, Schneider, 2006. $386 \mathrm{p}$.

Zainiev R.F. Succession of professionally oriented mathematical education in the system of «school-college-high school. Abstract diss. d-r. ped. sciences. Yaroslavl', 2012. 42 p. 


\section{Инновационные методы \\ обучения английскому языку взрослых}

\section{С.Е. Каплина}

Забайкальский государственный университет Россия, 672039, Чита, ул. Александро-Заводская, 30

Статья посвящчена описанию инноваччинных методов обучения взросльх. Сегодня инновационные методы и технологии обучения завоевывают все больщее признание и открывают новые возможности, связанные с созданием межличностного взаимодействия. Автор обрашает внимание на выбор методов, которые должны варьироваться в зависимости от цели обучения, возрастных групп и этапов психического развития. Структура современного прочесса обучения иностранным языкам взросльх и его результатов представлена автором. Обращено внимание на некоторые общие характеристики обучения взросльх иностранному языку, а также представлены четыре основополагающих принципа обучения взросльх иностранному языку. В соответствии с выбранными характеристиками и принципами автор считает необходимым использовать некоторые из инновационных методов обучения взросльх. Среди них представлены такие методы, как: метод непосредственной инструкции (Дж. Вихман и Дж. Грелл), метод электронного самонаправляемого обучения (Т.М. Бальхина), метод работы педагогической мастерской (Е.В. Невмержицкая), метод междисииплинарного проектирования (С.Е. Каплина). Основные методологические характеристики методов также описываются в статье.

Ключевые слова: обучение взросльх, инновационные методы, прочесс обучения, непосредственная инструкция, метод электронного самонаправляемого обучения, метод работы педагогической мастерской, междисциилинарное проектирование.

Статья написана при финансовой поддержке гранта программы ТЕМПУС IV Европейского Союза (проект «Создание сети университетских языковых центров для профессионального и личностного развития человека в рамках парадигмы «образование в течение всей жизни», № 544283-TEMPUS-1-2013-1-ES-TEMPUS-JPHES).

Научная специальность: 13.00.00 - педагогические науки. 